\title{
The effect of information technology on the quality of accounting information
}

\author{
Abubkr Ahmed Elhadi Abdelraheem ${ }^{a *}$, Asaad Mubarak Hussaien ${ }^{b}$, Mohammed Abaker Ahmed \\ Mohammed $^{c}$ and Yosra Azhari Elamin Elbokhari ${ }^{\mathrm{d}}$
}

\author{
${ }^{a}$ College of Science and Humanities Studies, Prince Sattam Bin Abdulaziz University, Al Aflaj, Saudi Arabia \\ ${ }^{b}$ College of Business Administration, Prince Sattam Bin Abdulaziz University, Hotat Bani Tamim, Saudi Arabia \\ ${ }^{c}$ College of Business Administration Taif University, Saudi Arabia
}

${ }^{d}$ PhD in Accounting- Sudan

\section{H R O N I C L E}

\section{Article history:}

Received: April 28, 2020

Received in revised format:

July 302020

Accepted: September 25, 2020

Available online:

September 25, 2020

Keywords:

Information Technology

Accounting Information System

Accounting Information Quality

\section{A B S T R A C T}

This paper aims to study the effect of using information technology on the quality of the accounting information by studying the dimensions of information technology (collecting, processing, storing, and sending data, and information) with a field study on the Nile Bank in Sudan. The researchers followed some descriptive analytical approach to conduct the field study. Researchers distributed (120) questionnaires and (104) of them were collected. The study concluded that dimensions of information technology (collecting, processing, storing, and transmitting data, and information) impact the dimensions of accounting information quality (relevance, reliability, understandability, consistency, comparability).

(C) 2021 by the authors; licensee Growing Science, Canada

\section{Introduction}

Accounting is one of the sciences that provide institutions with the information needed to make decisions in the service of projects and society in general, and this information is useful in making economic decisions by many parties, whether inside or outside the unit, as information in the contemporary time is wealth and optimal utilization achieves profits and success for the future plan and a guarantee of stability and development Institutions. The study aims to learn the relationship between the Information technology and accounting information quality at the Nile Bank in Sudan, the problem of study revolves around what is the impact of Information technology on accounting information quality at the Nile Bank in Sudan? According to the study problem, the following main hypothesis was formulated: There is a positive relationship between information technology and the quality of accounting information at the Nile Bank in Sudan. The researchers used descriptive analytical method

\section{Theoretical Framework}

\subsection{Information Technology}

Information Technology (IT) has significantly advanced during the past years, and the number of organizations that rely on a computer in the electronic operation of their statements also increased. Nowadays, companies use information technology to manage their data and present it to their users, especially electronic accounting systems (Ghasemi et al., 2011). E-accounting

* Corresponding author.

E-mail address: a.abdelraheem@psau.edu.sa (A. A. E. Abdelraheem) 
refers to electronic accounting, a term used to describe an accounting system that relies on computer technology for capturing and processing financial data in organizations (Laudon \& Laudon, 2011). Today use of Information Technology has become a strategic necessity for running a business and Information Technology (IT) has become a vital component of successful businesses. In fact, in every wing of the business, managers identify opportunities to forge ahead or to improve with the help of IT. One of the advantages of the use of IT in business functions is a better cost-performance ratio compared to that of traditional labor-intensive manual systems (ACAI). Information technology is the hardware, software and communication networks. Information technology facilitates data acquisition, processing, storage, delivery and sharing. In the European Union, the term information and communication technology are used instead of information technology to identify the convergence between traditional and modern information technology (Ward \& Griffiths, 1996). Information is the key for the development of today's enterprises and through computerization or establishing the information technology (IT), that information can be generated. Computing is an important strategy for creating a modern enterprise system to improve the quality of data, operations, and accounting outputs. Accounting information can help management, stakeholders, and other decision-makers strengthen the business, improve efficiency, and make a suitable decision (Brynjolfsson \& Hitt, 2000). In other words, businesses are encouraged to implement Computerized Accounting Systems (CAS), Computerized accounting systems are designed to automate all business processes and help companies handle all business transactions easily and cost effectively (Wang et al., 2013). Information technology specializes in the following jobs (Laudon \& Laudon, 2011; Setiyawati \& Doktoralina, 2019):

- Data collection: This is the first job that information technology can provide, and data collection is about obtaining data on the organization's operations from the internal and external environment.

- Processing: It is intended to perform mathematical and logical operations (analysis, classification, arrangement) on the data and converting them into information.

- Storage: storing information is an activity — an information system in which data and information are stored in an orderly manner to be used as output when the user needs it.

- Sending: It is intended to transmit information using various media, such as the Internet and optical fibers.

\subsection{Accounting Information System \& Accounting Information Quality}

Accounting information systems (AIS), is a system to collect, record, store, and process the data for providing the information for decision-making (Grande et al., 2011). According to Romney and Steinbart (2012), an accounting information system is a system for collecting and processing data to provide information necessary for decision-making. The accounting system provides information that can be used to make informed financial decisions. The information provided by accounting is primarily financial, and relates to specific institutions. The accounting information system consists of major subsystems: (1) the transaction processing system, (2) the general ledger and (3) the management reporting system and the subsystems to handle financial and non-financial transactions (Hall, 2012). The accounting information system is a structure that is incorporated into an entity, which uses physical resources and other components, to convert financial data into information to meet the information needed for users. Bodnar and Hopwood accounting information systems are collections of resources, such as humans and equipment, which are arranged to convert data into accounting information (Wilkinson et al., 2000; Ta \& Nguyen, 2020). The accounting information system is a way to obtain information by the management of the company that will be used for decisionmaking, it is an information system and if we are more accurate, then accounting is the practice of accounting theories in the field of economic activities and consists of information that is presented in a quantitative form (AICPA, 1966). According to Boockholdt (1999), the accounting information system is a group of subsystems working to collect, process data and discloses in financial reports to provide information for decision-making (Alkali et al., 2018).

\subsection{Quality of Accounting Information}

Accounting information is good if the information used is relevant and reliable, and the relevant information is that which influences the behavior of the decision-maker (Porter \& Norton, 2011). According to Riahi-Belkaoui (2004), good accounting information is primarily monetary and determinative information. According to Mamić Sačer et al. (2006) the accounting information produced by the accounting information system, according to its goal is to provide information to ensure the quality of accounting information to support planning, control, and analysis of the company's activity for assuring good information (Gelinas, 2012) is relevant information for decision-makers. The user has criteria that define the quality of the information to determine the quality of the decision by providing additional assurance of suitability, timeliness, accuracy, and completeness. Accounting information is good if it meets the requirements for accuracy, completeness, consistency and timeliness (Baltzan, 2012; Binh et al., 2020). According to Keiso et al. (2010), the quality of accounting information refers to the quality of accounting information and the efficiency and effectiveness of the accounting information system applied to serve the top management and help it achieve maximum productivity. Dimensions of accounting information quality are determined by: 
- Relevance: It means the efficiency of financial data and reports, and their success in serving their users through their ability to provide sufficient and appropriate information to make appropriate decisions so that this information is recognized as suitable for decision-making and presented correctly as well as its availability promptly.

- Reliability: It is the ability to rely on it. Accounting information is reliable if it is free from error and bias.

- Consistency: This characteristic is achieved when an organization uses a fixed accounting treatment from one period to the next without change.

- Understandability: It is a feature that helps the user of accounting information in determining the significance of the contents and presentation of financial reports.

- Comparability: This feature allows users of financial reports to compare accounting information between different periods to make their decisions.

\section{Methods}

The study population is represented by the Nile Bank in Sudan. The study sample consists of (administrators, accountants, technicians, and internal auditors) working in six branches of the Nile Bank - Khartoum State. researchers distributed (120) questionnaires, $104(87 \%)$ of them were collected. The researchers used simple linear regression analysis to find out the effect of the independent variable (information technology) $(\mathrm{X})$ with the four dimensions (data collection, data processing, data storage, sending information) on the dependent variable, which is the quality of accounting information (Y), Fig. 1 illustrates the model and variables of the study:

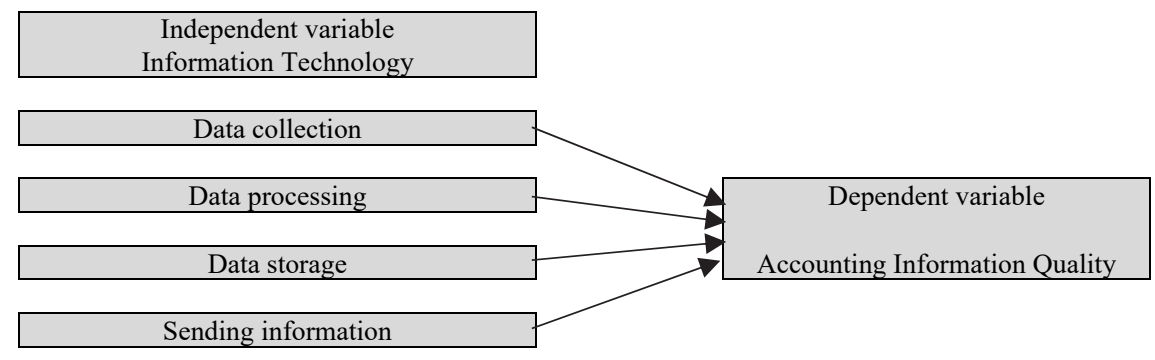

Fig. 1. Model and Variables of the Study

\subsection{Objective and Hypothesis of the Study}

The study aims to know the impact of Information technology on accounting information quality at the Nile Bank in Sudan, according to aim and problem of the study the following main hypothesis were formulated the main hypothesis:

$\mathrm{H}$ : There is an impact of information technology on the accounting information quality, and the following hypotheses are branched out from it:

$\mathrm{H}_{1}$ : There is an impact of data collection on the accounting information quality.

$\mathrm{H}_{2}$ : There is an impact of data processing on the accounting information quality.

$\mathrm{H}_{3}$ : There is an impact of data storage on the accounting information quality.

$\mathrm{H}_{4}$ : There is an impact of sending information on the accounting information quality.

\subsection{Hypothesis Testing}

The first hypothesis: The effect of data collection on the quality of accounting information

To validate the hypothesis, a simple linear regression is used in constructing the model where the data collection an independent variable (X1), and accounting information quality (Y) as a dependent variable, and Table NO (1) illustrates this: 


$$
\begin{array}{lrl}
\multicolumn{5}{c}{Y=1.124+0.713 X_{1}} \\
\text { t-value } & 7.020 & 20.97 \\
\text { Sig. } & 0.000 & 0.000 \quad \mathrm{R}^{2}=0.879 \quad \text { F-value }=411.01(0.000)
\end{array}
$$

Based on the results given in Eq. (1), we observe that all t-values are statistically meaningful when the level of significance is one percent. Also, F-value yields a meaningful value which means there is a linear relationship between independent variable and dependent variable, Moreover, R-Square is equal to 0.879 which means the independent variable can describe about $88 \%$ of the changes on dependent variable. Therefore, we can conclude that data collection influences positively on the quality of accounting information. In other words, an increase of one unit on data collection may increase the quality of accounting information by 0.713 . Thus, the first hypothesis of the survey is confirmed.

The second hypothesis: The effect of data processing on the quality of accounting information.

$$
\begin{array}{lll}
\multicolumn{5}{c}{Y=1.031+0.646 X_{1}} \\
\text { t-value } & 6.563 & 18.312 \\
\text { Sig. } & 0.000 & 0.000 \quad \mathrm{R}^{2}=0.830 \quad \text { F-value }=310.97(0.000)
\end{array}
$$

Based on the results given in Eq. (2), we can confirm that all t-values are statistically meaningful when the level of significance is one percent. In addition, F-value maintains a meaningful value which states there is a linear relationship between independent variable and dependent variable, Besides, R-Square is equal to 0.879 which means the independent variable can describe about $83 \%$ of the changes on dependent variable. Therefore, we can conclude that data processing influences positively on the quality of accounting information. In other words, an increase of one unit on data processing will increase the quality of accounting information by 0.646 . Therefore, the second hypothesis of the survey is confirmed.

The third hypothesis: The effect of data storage on the quality of accounting information.

$$
\begin{array}{lll} 
& Y=0.993+0.425 X_{1} \\
\text { t-value } & 29.160 & 16.104 \\
\text { Sig. } & 0.000 & 0.000 \quad \mathrm{R}^{2}=0.520 \quad \text { F-value }=204.18(0.000)
\end{array}
$$

According to the results given in Eq. (3), we can confirm that all t-values are statistically meaningful when the level of significance is one percent and a meaningful value for F-statistics means the existence of a linear relationship between independent variable and dependent variable, Moreover, R-Square is equal to 0.520 which indicates the independent variable can describe only about $52 \%$ of the changes on dependent variable and we can conclude that data storage influences positively on the quality of accounting information. This means that, an increase of one unit on data processing will increase the quality of accounting information by 0.425 and the third hypothesis of the survey is confirmed.

The fourth hypothesis: The effect of information distribution on the quality of accounting information.

$$
\begin{array}{rrr}
Y= & 1.002+0.504 X_{1} \\
\text { t-value } \quad 26.015 \quad 14.320
\end{array}
$$

Sig. $\quad 0.000 \quad 0.000 \quad \mathrm{R}^{2}=0.696 \quad$ F-value $=291.12(0.000)$

The information of the regression analysis in Eq. (3) confirms that all t-values are statistically meaningful when the level of significance is one percent and a meaningful value for F-statistics means the presence of a linear relationship between independent variable and dependent variable, Moreover, R-Square is equal to 0.696 which means the independent variable explains about $70 \%$ of the changes on dependent variable and we can conclude that data distribution influences positively on the quality of accounting information. This means that, an increase of one unit on data processing will increase the quality of accounting information by 0.504 and the last hypothesis of the survey is confirmed.

\section{Conclusion and Suggestion}

The study aimed to know the impact of information technology on the quality of accounting information at the Nile Bank - Sudan. The study has determined that information technology directly impacts the quality of accounting 
information by collecting, processing and storing data, sending information to its users, and the bank applying the four dimensions of information technology could contribute to achieve the property of relevance, reliability, understandability, consistency and comparability of accounting information, and consistency in processing and displaying accounting information. As this study was limited only to the information technology steps represented in collecting, processing and storing data, and sending information, and it did not study the effect of other aspects of information technology on the quality of accounting information, such as the effect of software and hardware on the quality of accounting information, based on the above, researchers suggest that more studies will be accomplished in the relationship between the use of accounting software, and the accounting information quality in commercial banks in Sudan.

\section{Acknowledgment}

This publication was supported by Deanship of Scientific Research, Prince Sattam Bin Abdulaziz University, Al-Kharj, Saudi Arabia.

\section{References}

Alkali, M., Zuru, N., \& Kegudu, D. (2018). Book value, earnings, dividends, and audit quality on the value relevance of accounting information among Nigerian listed firms. Accounting, 4(2), 73-82.

Baltzan, P., Phillips, A. L., Lynch, K., \& Blakey, P. (2008). Business driven information systems. New York: McGrawHill/Irwin.

Binh, V., Tran, N., Thanh, D., \& Pham, H. (2020). Firm size, business sector and quality of accounting information systems: Evidence from Vietnam. Accounting, 6(3), 327-334.

Boockholdt, J. (1999). Accounting Information Systems Transaction Processing and Control. The Mac-Graw-Hill companies, 5, 433-444.

Brynjolfsson, E., \& Hitt, L. M. (2000). Beyond computation: Information technology, organizational transformation and business performance. Journal of Economic Perspectives, 14(4), 23-48.

Gelinas, J.U. (2012). Accounting Information Systems. South Western, 19.

Ghasemi, M., Shafeiepour, V., Aslani, M., \& Barvayeh, E. (2011). The impact of Information Technology (IT) on modern accounting systems. Procedia-Social and Behavioral Sciences, 28(2011), 112-116.

Grande, E. U., Estébanez, R. P., \& Colomina, C. M. (2011). The impact of Accounting Information Systems (AIS) on performance measures: empirical evidence in Spanish SMEs. The International Journal of Digital Accounting Research, 11(1), 25-43.

Hall, J. A. (2012). Accounting information systems. Cengage Learning.

Institute of Chartered Accountants of India, Information Systems Control and Audit.

Kieso, D. E., Jerry,J. W., \& Warfield, T.D. (2010). International Accounting. $8^{\text {th }}$ ed., John Wiley \& Sons, NY.

Laudon, K. C., \& Laudon, J. P. (2011). Essentials of management information systems. Upper Saddle River: Pearson.

Laudon, K.C., \& Laudon, J.P. (2011). Management Information Systems: Managing the Digital Firm (Upper Saddle River, NJ: Prentice Hall).

Mamić Sačer, I., Žager, K., \& Tušek, B. (2006). Accounting information system's quality as the ground for quality business reporting. In IADIS International conference, e-commerce 2006 (p. 59).

Porter, G.A., \& Norton, C, L., (2011). Using Financial Accounting Information: The Alternative to Debits and Credits. $7^{\text {th }}$ ed., South-Western Cengage Learning: USA, 29.

Romney, M. B., \& Steinbart, P., J. (2012). Accounting Information Systems. Pearson Education Limited,686.

Riahi-Belkaoui, A. (2004). Accounting theory. Cengage Learning EMEA.

Setiyawati, H., \& Doktoralina, C. (2019). The importance of quality accounting information management in regional governments in Indonesia. Management Science Letters, 9(12), 2083-2092.

Ta, Q., \& Nguyen, T. (2020). Impact of factors on the quality of accounting information system in civil engineering construction enterprises. Management Science Letters, 10(13), 2985-2992.

Wang, D. H. M., \& Huynh, Q. L. (2013). Effects of environmental uncertainty on computerized accounting system adoption and firm performance. International Journal of Humanities and Applied Sciences, 2(1), 13-21.

Ward, J. M., \& Griffiths, P. M. (1996). Strategic planning for information systems. John Wiley \& Sons, Inc.

Wilkinson, J. W., Cerullo, M. J., Raval, V., \& Wong-On-Wing, B. (2000). Accounting Information Systems-Essential Concepts and Applications. John Willey and Sons. Inc., USA. 
(C) 2020 by the authors; licensee Growing Science, Canada. This is an open access article distributed under the terms and conditions of the Creative Commons Attribution (CC-BY) license (http://creativecommons.org/licenses/by/4.0/). 